\title{
HADİS/SÜNNET IŞIĞINDA KIZ ÇOCUKLARINA VERILEN DEĞER
}

Gönderim Tarihi: 31.12.2015

Kabul Tarihi: 29.02.2016

Orhan YILMAZ*

\section{Öz}

$\mathrm{Bu}$ makalede hadis ve sünnet $1 s ̧ ı$ ğında $\mathrm{k} 1 \mathrm{z}$ çocuklarına verilen değer ele alınmakta ve dünden bugüne kız çocuklarına ikinci sınıf evlat nazarı ile bakan anlayış eleştirilmektedir. İnsanlık tarihi boyunca hemen hemen her toplumda fiziksel ve ruhsal özellikleri nedeniyle kız çocukları erkeklere oranla ikinci sırada önemi haiz evlat konumunda olmuştur. Genellikle aileler erkek çocuk sahibi olduklarında kendilerini daha güvende ve şanslı saymışlardır. Erkek çocuk doğuran kadınlar akraba ve kocaları tarafından taltif edilirken, kız çocuğu doğuran kadınlara aynı ilgi ve alaka gösterilmemiştir. Kız çocuklarına karşı olumsuz tutum Hz. Peygamber öncesi dönemde Mekke toplumunun da en karakteristik özelliklerinden biri olmuştur. Cahiliye devri olarak bilinen bu dönemde kız çocuklarının diri diri toprağa gömüldüğüne bile rastlanmıştır. Hz. Peygamber Arap toplumu özelinde kız çocuklarına yönelik süregelen bu kötü geleneği değiştirmek, kız çocuklarının değerini artırmak ve onları toplumda saygın bir konuma getirmek için tüm insanlığa örneklik teşkil edecek davranışlar sergilemiştir.

Anahtar Kelimeler: Hadis, Sünnet, Kız çocukları, Cahiliye dönemi, Merhamet.

\section{Abstract}

The Value of Daughters in the Light of Hadith/Sunnah

In this article, under the light of the hadith and the Sunnah the value of the daughters has been dealt with and the opinion that the daughters are second class child has been criticized. Along human history generally the daughters, because of their physical and psychological weakness, have been accepted less important than boys in many societies. When families have sons they have felt themselves happy and lucky. Women who give birth to sons have been respected by their husbands and relatives but who give birth to girls have been denigrated. Before Muhammad (pbuh) the negative behavior against daughters

* Yrd. Doç. Dr., Bozok Üniversitesi, İlahiyat Fakültesi, Temel İslam Bilimleri Bölümü. Assistant Professor, Bozok University, Faculty of Theology, Department of Basic Islamic Studies. Yozgat/Turkey (orhanyilmaz04@hotmail.com). 
174 | Orhan YILMAZ

was one of the best characteristic of Meccan people also. According to some researches in this era, also known as pre-Islamic age of ignorance, some daughters have been buried alive. The Holy Prophet Muhammad has recommended to all Muslims to be in good behavior towards to the girls and he was the best example in this issue.

Keywords: Hadith, Sunnah, Daughter, Pre-Islamic-age, Mercy.

\section{Giriş}

İslâmiyet'ten önce Arap toplumunda insan fitratına ve İslâm'in temel prensiplerine aykırı pek çok örf, adet, gelenek ve görenekten söz edilmiştir. Bunlardan biri de kız çocuklarını hor ve hakir görme geleneği idi. Cahiliye dönemi olarak bilinen bu yıllarda kız çocuklarına değer verilmediği, kızı olanların bundan utanç duyduğu ve onlardan kurtulma yolları aradığı hatta bazı kabilelerde küçük kız çocuklarının diri diri toprağa gömüldüğü bile haber verilmiştir. Tarih, tabakât ve hadis kitaplarında yer alan kız çocukları ile ilgili bu haberlerin, cahiliye kültürünü anlatan ayetlerle örtüşmesi, bu haberlerin sihhati konusunda önemli ipuçları vermektedir. ${ }^{1}$

Insanlık tarihi boyunca umumiyetle kız çocukları erkeklere oranla değersiz kabul edilip horlanan ve ezilen evlat konumunda olmuştur. Özellikle hayat şartlarının ağır, savaşların yaygın olduğu dönemlerde fiziksel gücü ve dayanıklılığından dolayı erkek çocukları daha çok istenen, kızlar ise zayıf ve bakıma muhtaç oldukları gerekçesi ile istenmeyen evlat muamelesi görmüştür. ${ }^{2}$

\footnotetext{
Konu ile ilgili rivayetler ve yer aldıkları kaynaklar ileride zikredilecektir.

2 Gerek Doğu, gerekse Batı olsun eski hukuk sistemlerinde kadınların statü bakımından erkeklere denk olmadığı, onların pek çok haklardan mahrum bırakıldığı, kadın haklarının en ileri olduğu ülkelerden biri olan Fransa'da bile ilk kez 1836 yılında kız çocuklarının eğitimi için bir okul açıldığı, İngiltere'de ise 1948'e kadar Cambridge Üniversitesi'ne kızların kabul edilmediği bilinen gerçeklerdir. Avrupa toplumunun 19. yüzyıla kadarki kadın alg1sı Arap toplumunun cahiliye dönemindeki kadın algısından farklı değildi. Fransız filozof Proudhon 1858 yılında yaptığı kadın tarifi ile Avrupa toplumundaki kadın algısını ortaya koymuştur. O kadını şöyle tarif etmiştir: "Kadın başka mahlûktur. Çünkü o eksiktir. Onun cinsiyeti ona eksik olma tabiatını vermektedir. Hem tabiatı icabı hem de adaletin gereği olarak o, erkeğin üçte birine bile denk değildir." Detaylı bilgiler için bkz. İbrahim Canan, Peygamberimizin Sünnetinde Terbiye (İstanbul: Tuğra Yayınları, 1977), 335-336; Nurettin Gülaçtı,
} 
$\mathrm{K}$ zz çocuklarının istenmeme ölçüsü ya da hakir görülüp aşağılanma biçimi ve oranı toplumdan topluma, coğrafyadan coğrafyaya değişiklik arz etmiştir. Yüce Allah'ın gönderdiği peygamberler ve onlara tabi olanlarla bazı bilge kişiler kız çocuklarına karşı süregelen bu negatif tutumu değiştirme mücadelesi vermişlerdir. Kadınların haklarını korumak için başlatılan bu mücadele farklı isimler altında değişik şekillerde bugüne kadar gelmiştir. ${ }^{3}$

Araştırmalarımıza göre özellikle az gelişmiş veya gelişmemiş ülkelerde temel hak ve özgürlükler alanında kadınların/kız çocukların aleyhine olacak şekilde cinsiyete dayalı ayrımcılık yapılmaktadır. Gelişmiş ülkelerde ise ekonomik, sosyal ve siyasal alanda cinsiyete dayalı ayrımcılığı ortadan kaldırmak ve kadınları hayatın her alanında daha etkin kılmak için yoğun çalışmalar yapılmasına rağmen, bugüne kadar istenilen düzeyde bir başarı elde edilebilmiş değildir. ${ }^{4}$

Ülkemizde yasal olarak eşit haklara sahip olsalar da hem yanlış dini yorumlar hem de örf, adet ve geleneklerin etkisi ile olsa gerek, kız çocukları çeşitli haklardan mahrum bırakılmaktadır. Doğu, Güneydoğu ve Karadeniz başta olmak üzere çeşitli bölgelerimizde çocuklar arasında cinsiyet ayırımı yapılmakta, erkek çocukları kızlara oranla daha değerli kabul edilmektedir. Örneğin bazı yörelerimizde babalar çocuklarının sayısını bildirirken sadece erkekleri sayarlar, kızları buna dahil etmezler. Bazı yörelerimizde ise kız çocukları eğitim ve öğretim gibi en temel haklardan bile kız oldukları için mahrum bırakılmaktadırlar. Nitekim toplumun erkek çocukları üstün gören kızları ise aşağılayan bu anlayışı deyim ve atasözlerimize de yansımıştır. “Oğlan doğuran övünsün, kız doğuran dövünsün", "oğlan ocak malı, kız el malı", "kızını dövmeyen, dizini döver" onlardan sadece birkaçıdır. ${ }^{5}$

Bilindiği üzere İslâm dini ortaya koyduğu norm ve formlarla insan fıtratına aykırı örf, adet, gelenek ve görenekleri ya doğrudan ya da

"Sanatsal Bir Obje Olarak Kadın ve Bazı Toplumlarda Kadına Bakış", İdil, Sanat ve Dil Dergisi, 1/2 (2012): 83-89.

3 Kadın haklarının tarihi gelişim süreci ile ilgili geniş bilgi için bkz. İhsan Şerif Kaymaz, “Çağdaş Uygarlığın Mihenk Taş: Türkiye'de Kadının Toplumsal Konumu”, Atatürk Yolu Dergisi, 12/46 (2010): 333-366.

4 Bkz., European Commission, Strategy for equality between women and men 2010-2015 (Belgium: Publications Office of the European Union, 2011), 3.

5 Geniş bilgi için bkz. Abdurrahman Kasapoğlu, “Kur'ân'a Göre Çocuklar Arasında Cinsiyet Ayrımcılığı”, Fırat Üniversitesi İlahiyat Fakültesi Dergisi, 10/1 (2005): 75-96. 


\section{6 | Orhan YILMAZ}

tedrici olarak kaldırma yoluna gitmiştir. İslâm'ın kaldırmak için mücadele ettiği kötü davranışlardan biri de yukarıda ifade ettiğimiz kız çocuklarına yönelik negatif yaklaşım olmuştur.

Hz. Peygamber çocuklar arasında cinsiyetten kaynaklanan bir üstünlüğü dile getirmemiştir. Aşağıda ele alacağımız bazı rivayetlere göre Hz. Peygamber, iyi muamele etme konusunda kızları öncelemiştir. Hatta o, bir kimsenin iki veya üç kız çocuğunu yetiştirmesi ve onlara iyi muamele etmesi halinde kendisi ile cennette komşu olacağı müjdesini vermiştir.

Hz. Peygamber'in kız çocukları ile ilgili tavsiye ve telkinleri sadece anne ve babaya yönelik değil, tüm Müslümanları kapsar mahiyettedir. Yani o, ümmetine kendi kızlarına iyi muamele etmelerini tavsiye ettiği gibi başkalarının kız çocuklarına da iyi muamele etmelerini tavsiye etmiştir.

Kız çocuklarının statüsünü artırmaya yönelik bu nebevi telkinler ve tavsiyeler etkili olmuş, Müslüman toplumlarda kız çocuğu algısı müspet yönde önemli değişiklikler göstermiştir. Ancak kız çocuklarına yönelik bu değişim İslam toplumlarında hiçbir zaman sünnette bildirilen düzeye ulaşmamıştır. Hatta zaman zaman Hz. Peygamber'in bu konudaki ögü̈leri unutulmuş, kız çocuklarını hakir görme anlayışı devam etmiştir.

Araştırmalarımıza göre genel anlamda kadınların toplumdaki yeri, hakları ve sosyal statüleri konularında varit olan rivayetler hadis ilmi kriterleri doğrultusunda tetkik edilmiş ${ }^{6}$ buna karşın kız çocuklarının korunması, bakımı ve sosyal statülerinin yükseltilmesi hakkında varit olan hadisler müstakil bir başlık altında incelenmemiştir.

Biz bu çalışmamızda kız çocuklarını koruyup kollamanın, evlat edinmenin, yetiştirip büyütmenin fazileti ile ilgili hadisleri ele alıp senet ve metin açısından inceleyeceğiz. Söz konusu rivayetlerin tarihi arka planı, vürûd sebepleri ve kaynak değerleri üzerinde duracağız. Amacımız hadis teknikleri açısından incelediğimiz bu rivayetler ışığında kız çocuklarına özellikle de kimsesiz kız çocuklarına karşı toplumun daha duyarlı olmasını sağlamak ve bu konuda İslâm'ın getirdiği ahlaki

6 Bkz., Hidayet Şefkatli Tuksal, Kadın Karşıtı Söylemin İslam Geleneğindeki İzdüşümleri (Ankara: Otto Yayınları, 2012); Veli Aba, "Kadınların Hukuki ve Sosyal Statülerine İlişkin Hadisler" (Yüksek lisans tezi, Erciyes Üniversitesi Sosyal Bilimler Enstitüsü, 2003). 
ilkeleri hatırlatmaktır. Ayrıca "Çocuk Esirgeme", "Sevgi Evleri" ve "Yetimhane" gibi resmi kurumlarda barınan kimsesiz kız çocuklarının bakımlarını üstlenme konusunda ailelerin bilinçlenmesini sağlamaktır.

\section{I- Cahiliye Döneminde Kız Çocukları}

Bilginin zıddı anlamındaki cahiliye kelimesi Arapların İslam'dan önceki dini ve sosyal hayatlarını ifade etmek için kullanılan bir terimdir. Terkip şeklinde kullanılan "cahiliye dönemi" ise İslamiyet'ten önceki zaman dilimini karşılamaktadır. "Cahiliye adetleri", "cahiliye anlayışı", "cahili yaklaşım" şeklindeki terkipler cahiliye dönemindeki tutum ve davranışlara atıfta bulunmak için kullanılmaktadır. ${ }^{7}$

Cahiliye döneminde kı çocuklarına yönelik tutum ve davranışların nasıl olduğu ayet, hadis ve tarihi vesikalar ışığında bilinirse Hz. Peygamber'in bu konudaki sünneti ve mesajları daha iyi anlaşılacaktır.

\section{a. Cahiliye Dönemini Anlatan Ayetlerde Kız Çocukları}

İslâm'dan önce kız çocuklarının statüsü hakkında bilgi veren elimizdeki en önemli kaynaklar Kur'ân'1-Kerîm, tefsir kitapları, hadis mecmuaları ve tarihi vesikalardır. Bu kaynakların en sağlamı hiç şüphe yok ki kesin bilgi ifade eden Kur'ân-1 Kerîm'dir. Dolayısıyla cahiliye döneminde kız çocuklarının değeri ile ilgili en önemli ve en doğru bilgileri Kur'ân'da bulmak mümkündür. Cahiliye dönemini anlatan bazı ayetlerde cinsiyet ayırımı yapılmaksızın geçim sıkıntısına düşme korkusu ile çocukların istenmediği ya da doğan çocukların öldürüldüğü ifade edilmektedir. ${ }^{8}$ Bazı ayetlerde ise Arap toplumunda kız çocuklarının statüsü müstakil olarak ele alınmıştır. Bir kısmını aşağıda naklettiğimiz bu ayetlerde cahiliye toplumunun kız çocuklarına değer vermedikleri, onları hor ve hakir gördükleri, kız babası veya annesi olmak istemedikleri bildirilmiştir. Örneğin; Nahl sûresinde müşriklerin, değer verdikleri şeyleri kendilerine değersiz saydıkları kızları ise Allah'a nispet ettikleri haber verilmiştir. ${ }^{9}$ Eşi kız çocuğu doğuran müşrik bir babanın psikolojik durumu ise şu çarpıcı ifadelerle anlatılmıştır; "Onlardan biri kız çocuğu ile müjdelendiği zaman içi öfke ile dolarak yüzü simsiyah kesilir.

7 Geniş bilgi için bkz., Mustafa Fayda, "Cahiliye", Türkiye Diyanet Vakfı İslam Ansiklopedisi (Ankara: TDV Yayınları, 2012), 7: 17-19.

$8 \quad$ Bkz., En'am, 6/136, 137, 140, 151; Mümtehine, 60/12.

9 Nahl, $16 / 57$. 
178 | Orhan YILMAZ

Kendisine verilen kötü müjde yüzünden halktan gizlenir. Şimdi onu aşă̆ılanmış olarak yanında mi tutsun yoksa topră̆a mi gömsün?"10 “Onlardan biri Rahman'a isnat ettiğ $i k \imath$ çocuğu ile müjdelenince hiddetlenerek yüzü simsiyah kesilir"11

Cahiliye döneminde kız çocuklarına karşı en kötü muamele örneği ise onların diri diri toprağa gömülmesi (ve'dü'l-benât) dir. İslâmiyet'ten önce bazı kabilelerde yaygın olduğu bilinen bu çirkin davranış ayet ve hadislerde şiddetle kınanmıştır. Tekvir sûresinde kız çocuklarını diri diri toprağa gömen cahiliye dönemi müşriklerinin işledikleri bu suçtan dolayı hesaba çekilecekleri ve muhtemelen ağır bir cezaya maruz

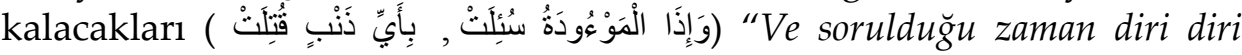
topră̆a gömülen kıza; hangi günahı yüzünden öldürüldü diye?"12 ifadeleri ile dile getirilmiştir.

Beğavî (ö. 510/1117) bu ayette geçen أَدَّ kوءودة kelimesinin kökünden türemiş ismi mef' ûl olduğunu ve diri diri toprağa gömülen kız çocuğu anlamına geldiğini ifade etmiştir. ${ }^{13}$ Ayette geçen ifadeye uygun olarak kız çocuklarının öldürülmesi dini metinlerde "وأد البنات" terkibi ile kullanılır hale gelmiştir.

Cahiliye döneminde geçim sıkıntısı veya başka sebeplerle çocukların öldürüldüğünü bildiren başka ayetler de vardır. Mezkûr ayetlerde bu çirkin eylemin detayları hakkında fazla bilgi verilmemekte ancak bu eylemin büyük bir suç olduğu, bu suçu işleyenlerin şiddetle uyarıldığı görülmektedir. ${ }^{14}$

\section{b. Cahiliye Dönemini Anlatan Rivayetlerde Kız Çocukları}

Muhaddis, müfessir ve tarihçilerin verdiği bilgilere göre cahiliye döneminde kız çocuğu doğurmaktan utanan bir kadın doğum sancıları tuttuğu zaman çöle gider, bir çukur kazıp, o çukurun başında doğum yapardı. Eğer kız çocuğu dünyaya getirirse onu çukura atıp gömerdi, erkek çocuk dünyaya getirirse onu alıp eve dönerdi ${ }^{15}$. Bazı rivayetlerde ise bir kız çocuğu dünyaya geldiği zaman eğer yaşamasına izin verilirse ona yünden veya kıldan bir cübbe giydirilir, çölde deve güttürülürdü.

\footnotetext{
$10 \quad$ Nahl, 16/58-59.

11 Zuhruf, 43/17.

12 Tekvir, 81/8, 9 .

13 و هي الجارية المدفونة حية Bkz. Ebu Muhammed el-Huseyn b. Mes'ud el-Beğavi, Tefsîru'lBeğavî, thk. Muhammed b. Abdillah el-Münir (Riyad: Daru Tayyibe, ty.), 8: 348.

14 İsra, 17/31; En'am, 6/136, 137, 140, 151; Mümtehine, 60/12.

15 Beğâvî, Tefsîru'l-Beğavî, 8: 348.
} 
Eğer öldürülecekse altı yaşlarına kadar beklenir sonra da çöle götürülüp kazılan çukura atılır ve üzeri toprakla kapatılırdı. ${ }^{16}$

Cahiliye döneminde kız çocuklarının öldürüldüğüne dair en çarpıcı örneklerden biri Beyhakî (ö. 458/1066) tarafından kaydedilmiştir. Anlatıldığına göre Temim kabilesinden Kays b. Asım Hz. Peygamber'e gelip cahiliye döneminde sekiz kız çocuğunu diri diri toprağa gömdüğünü söylemişti. Hz. Peygamber ceza olarak ona her bir kızı için bir köle azat etmesini emretmişti. ${ }^{17}$ Beyhâki' nin naklettiği bu rivayetin bir varyantında yukarıda anlatıldığı şekilde Hz. Ömer, diğer bir varyantında ise Kays b. Asım bizzat kendisi Hz. Peygamber'e gelerek başından geçen olayı anlatmıştır. Hz. Ömer'in naklettiği haberde Kays b. Asım'ın sekiz, kendi anlattığı varyantta ise 12 veya 13 kızını diri diri toprağa gömdüğü ifade edilmiştir.18 Bir başka rivayete göre Hz. Ömer'e (واذالمو وودة سئلت ) ayetinin anlamı sorulunca o, Kays b. Asım ile Hz. Peygamber arasında geçen diyalogu anlatmıştır. Bu rivayete göre Hz. Peygamber Kays'a gömdüğü her kız çocuğu için bir köle azat etmesini emredince Kays; “Ey Allah'ın Rasûl'ü! benim develerim var" demişti. Bunun üzerine Hz. Peygamber ona her bir çocuk için bir deve kurban etmesini emretmişti. ${ }^{19}$

Birinci derecede önemli hadis kaynaklarında yer almayan bu rivayet, senedindeki inkıtadan dolayı zayıf haber olarak değerlendirilmiştir. ${ }^{20}$ Cahiliye döneminde kı çocuklarına karşı toplumun yaklaşımını güzel bir şekilde ortaya koyan ve sahih rivayetlere muhalefet etmeyen bu haberin müteahhir hadis ve tarih kitaplarında yer alması $^{21}$ şahit ve delil olarak kullanılabileceğini mümkün kılmaktadır.

16 Celaleddin b. Abdirrahman es-Suyûti, ed-Dürrü'l-mensûr fi't-tefsîr bi'l-me'sûr (Beyrut: Dâru İhyâ, 1993) 8: 428; Ebû'l-Fadl Şihabuddin es-Seyyid Mahmud Alûsî, Rûhu'lme'âni fi tefsîr'l-Kur'âni'l-'azîm ve's-seb'i'l-mesâni (Beyrut: Dâru İhyâi't-Turasi'l-Arab, 1985), 30: 67.

17 Ahmed b. Huseyn b. Ali b. Musa el-Beyhâki, es-Sünenü'l-kübra, thk. Abdu'l-Kadir 'Ata (Beyrut: Dâru'l-Kütübi'l-'İlmiyye, 2003), 8: 202.

18 Beyhâki, es-Sünenü'l-kübra, 8: 202; Suyûti, Câmi'u'l-ehâdis, 26: 415.

19 Bkz., Alâu'd-din Ali b. Hüsâmu'd-din el-Muttaki, Kenzu'l-'ummâl fî süneni'l-ekvâl ve'lef'âl (Medine: Müessesetü'r-risale, 1981), 2: 546.

20 Bkz. İbnü'l-Mülakkın, el-Bedru'l-münîr, thk. Mustafa Ebu'l-Ğayz (Riyad: Dâru'l-Hicre, 2004), 8: 505.

21 Bkz. Muttaki, Kenzu'l-'ummâl fî süneni'l-ekvâl ve'l-ef'âl, 2/546; Ahmed b. Huseyn b. Ali b. Musa el-Beyhâki es-Sünenü's-suğra, thk. Abdu'l-Mu'ti Emin Kal'acı (Pakistan: Câmi'atu'd-dirâsati'l-İslâmiyye, 1989), 3: 253. 
Kız çocuklarına karşı cahiliye Araplarının tutumunu ortaya koyan bir başka olay Dârimî (ö. 255/869) tarafından nakledilmiştir. Mezkûr rivayete göre bir adam Hz. Peygamber'e cahiliye döneminde yaşadığı bir olayı şöyle anlatır; "Ya Rasûlallah! biz cahiliye döneminde putlara tapar, çocukları öldürürdük. Benim küçük bir kızım vardı. Bu kız beni çok severdi. Çağırdığım zaman koşa koşa yanıma gelirdi. Bir gün onu yanıma alıp evden uzaklaştım ve kolundan tutarak bir kuyuya attım. Kuyudan uzaklaşırken duyduğum son sözleri "babacığım, babacığım" çı̆̆lıklarıydı. Bu hikâyeyi dinleyen Allah'ın Rasûlü çok üzülür ve gözlerinden yaşlar akmaya başlar. Orada bulunanlardan biri olayı anlatan şahsa; "Rasûlullah'ı üzdün" diyerek çıkışır. Hz. Peygamber; "Ona müdahale etmeyin bırakın duygularını istediği gibi anlatsın" der ve olayı tekrar anlattırır. Hz. Peygamber sakalı ıslanıncaya kadar ağlar. Eserin muhakkiki bu hadisin mürsel râvilerinin ise sika olduğunu bildirmiştir. ${ }^{22}$

Cahiliye döneminde ve'dü'l-benâtın varlığını ve yaygınlığını gösteren bir başka örnek Hz. Peygamber'in Medinelilerle yaptığ sözleşmedir. Akabe bîatı olarak bilinen bu sözleşmeye göre Hz. Peygamber onlardan şirk koşmayacakları, zina etmeyecekleri, iftirada bulunmayacakları ve çocuklarını öldürmeyeceklerine dair söz almıştı. ${ }^{23}$ Hz. Peygamber'in kendisine gelip bîat etmek isteyenlerin bîatını kabul etme şartlarından birinin ve'di terk etmeleri olduğu ayetle de sabittir. Yüce Allah bu hususta; "Ey Peygamber! İnanmış kadınlar Allah'a hiçbir şeyi ortak koşmamak, hırsızlık yapmamak, zina etmemek, çocuklarını öldürmemek... şartıyla sana bîat etmek üzere geldikleri zaman onların bîatlerini kabul et." buyurmuştur. ${ }^{24}$

Esma bt. Ebi Bekir'den gelen bir rivayete göre cahiliye döneminde hanif dini üzere yaşayan Zeyd b. Amr b. Nufeyl (ö. 606/1209) ve'd

22 Abdullah b. Abdurrahman Dârimî, es-Sünen, Mukaddime (Arabistan: Dâru'l-Muğni, 2000), 1: 3-4, Şerafüddin Hüseyin b. Abdullah et-Tîbî, el-Kâşif 'an hakâiki's-sünen (Şerhu't-Tîb̂̂ 'alâ Mişkâti'l-Mesâbîh), thk. Abdülhamid Hindâvî (Mekke: Mektebetü Mustafa el-Bâz, 1999), 2: 575; Ebu'l-A'lâ Mevdûdi, Tefhimu'l-Kur'ân, çev. Komisyon (İstanbul: İnsan Yayınları, 1986), 7: 49.

23 Ebu'l-Huseyin Müslim b. Haccac el-Kuşeyri, el-Câmi'u's-sahîh (İstanbul, Çağrı Yayınları, 1981), Hudud, 43; Ahmed b. Hanbel, Müsned, thk. Şuayb Arnavut (Beyrut: Müessesetü'r-risale, 2001), 5: 321; Muhammed Hamidullah, İslâm Peygamberi, çev. Salih Tuğ (Ankara: Yeni Şafak, 2003), 1: 154.

24 Mümtehine, 60/12. 

yapmamaları konusunda Kureyşlileri uyarmış ve öldürülmek üzere olan bazı kız çocuklarının bakımlarını üstlenerek onların hayatta kalmalarını sağlamıştır..$^{25}$

Muğire b. Şu'be'den gelen bir rivayete göre ise Hz. Peygamber ashabına hitap edip Yüce Allah'ın onlara üç şeyi haram kıldığını bildirmiştir. Bu üç şeyden biri de Ve'd'l- benâttır. Sahih ve sabit olduğu bildirilen bu rivayet Buhâri'nin Sahîh'i dahil pek çok muteber hadis kitabında değişik târiklerle yer almıştır. ${ }^{26}$

Ve'dü'l-benâtla ilgili bazı rivayetler İslâm'ın temel prensipleri ile teâruz halinde olduğu için tenkit edilmiştir. Bu rivayetlerden biri de Ahmed b. Hanbel (ö. 241/856) ve Ebû Dâvud (ö. 275/889) tarafından iki tarikle kaydedilmiş meşhur bir hadistir. Söz konusu rivayet Ebû Dâvud'un Süneninde Abdullah b. Mes'ud tarafından merfu haber, 'Âmir

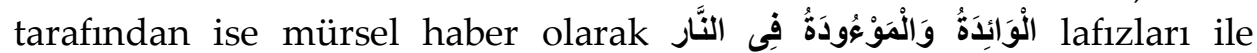
kayıtlıdır. ${ }^{27} \mathrm{Bu}$ habere göre Hz. Peygamber; "Kızını toprağa gömen anne ve gömülen kız çocuğu cehennemdedir" buyurmuştur. Kelimelerin ilk anlamına bağlı kalarak yaptığımız bu tercümeye göre kızını gömen anne ve diri diri gömülen $\mathrm{klz}$ çocuğu cehennemlik olarak bildirilmiştir.

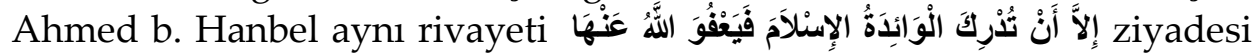
ile kaydetmiştir..$^{28}$ Yani hadisin devamında "eğer kızını gömen anne daha sonra Müslüman olursa Allah onu affeder" ibaresi vardır.

İslam'da çocukların masum olduğu anlayışına muhalif olduğu

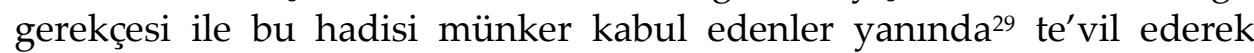
teâruzu gidermeye çalışanlar da olmuştur. Söz konusu hadisin şerhlerinde; "çünkü o, müşrik bir annenin çocuğudur." Yani ölen çocuk (mev'ûde) ve onu öldüren anne (vâide) Müslüman olmadığı için her ikisi de bu cezaya müstehaktır denilmiştir. ${ }^{30}$ Bir başka açılamada ise bu

25 Muhammed b. İsmâil el-Buhârî, el-Câmiu's-sahîh (İstanbul: Çağrı Yayınları, 1981), Menâkıbu'1-Ensar, 24

26 Buhâri, İstikrâd, 19; Ahmed b. Hanbel, Müsned, 37: 179; Dârimî, Rikâk, 38.

27 Ebû Dâvud es-Sicistânî, Sünen, thk. Şuayb Arnavut (Beyrut: Dâru risâleti'l-alemiyye, 2009), 7: 99.

28 Ahmed b. Hanbel, Müsned, 24: 68.

29 Bkz. Ahmed b. Hanbel, Müsned, 25: 268.

30 Ebû Dâvud, Sünen, 4: 366; Ahmed b. Hanbel, Müsned, 25: 228. 
hadiste geçen mev'üdenin yetişkin olduğu söylenerek illet giderilmeye çalışılmıştır. ${ }^{31}$

Bazı şerhlerde ise bu hadisteki ifadelerin umumi olmadığı, kızını öldüren bir kadına münhasır olduğu bildirilmiştir. Yani Hz. Peygamber çocuğunu öldürdüğü söylenen ve kâfir olduğu da bilinen bir kadını cehennemlik ilan etmiştir. Açıklamanın devamında bu hadise dayanarak ölen çocuğun (mev'üde) cehennemlik olduğunu söylemenin mümkün olamayacağı bildirilmiş ancak çocuğun niçin cehennemde olacağı ile ilgili her hangi bir açıklama yapılmamıştır. ${ }^{32}$

Tîbî (ö. 743/1343) rivayette zikri geçen annenin Müleyke isimli bir kadın olduğunu kaydetmiştir. Anlatıldığına göre iki kişi $\mathrm{Hz}$. Peygamber'e gelip anneleri olan Müleyke'nin cahiliye döneminde bir kızını diri diri toprağa gömdüğünü ve bu filinden dolayı bir cezaya uğrayıp uğramayacağını sormuşlar. Bu soruya cevap mahiyetinde $\mathrm{Hz}$.

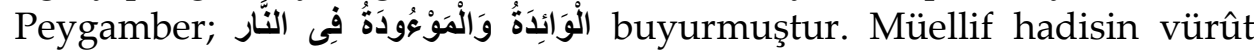
sebebini zikrettikten sonra "bu hadis her ne kadar hususi bir olay üzerine vârit olsa da anlamı umumidir" şeklinde bir yorum yapmış, hadiste geçen kelimelere farklı anlamlar yüklemek suretiyle de metindeki anlamı makul hale getirmiştir. Ona göre ismi fail olan "elvâidetü" kelimesi "çocuğunu öldüren anne" değil çocuğun ölümünü gerçekleştiren doktor veya ebe anlamında kullanılmıştır. "el-mev'üdetü" ise gerçekte "el-mev'üdetün leha" anlamında olup gömülen çocuğu değil, çocuğu gömülen anne"yi ifade etmektedir. Tîbî bu görüşünü desteklemek için cahiliye döneminde ve'din uygulanış biçimi hakkında farklı bir bilgiye yer vermiştir. Onun anlattığına göre cahiliye döneminde doğumu yaklaşan bir kadın ebe ile birlikte çöle giderdi. Eğer kadın kız doğurursa ebe çocuğu önceden açllan çukura gömerdi ve anne ile birlikte eve dönerlerdi. ${ }^{33}$

Bu açıklamalar tatmin edici bulunmadığ için, hem hadisin metnine hem de yapılan şerhlere yönelik tenkitler devam etmiştir. Bu tenkitleri; "Bu hadisin devamındaki ibareye göre "çocuğunu öldüren müşrik anne daha sonra pişman olsa ve Müslüman olup tövbe etse günahın

31 Muhammed b. Hibban, Sahîh-i ibn Hibban bi tertîbi ibn Belban, thk. Şuayb Arnavut (Beyrut: Müessesetü'r-risale, 1993), 16: 521.

32 Ebü't-Tayyib Muhammed Şemsü'l-Hak b. Emîr Alî ed-Diyânüvî el-Azîmâbâdî, 'Avnu'l-ma'bûd şerhu Sünenî Ebî Dâvồd (Beyrut: Dâru'l-kütübi'l-'ilmiyye, 1415), 12: 322; Tî̉îi, el-Kâşif 'an hakâiki's-Sünen, 2: 575.

33 Tîbî, el-Kâşif 'an hakâiki's-Sünen, 2: 575. 
cezasından kurtulma şansına sahiptir" denilmiştir. Oysa öldürülen çocuk böyle bir şansa sahip değildir. Masum bir çocuğun hem diri diri gömülmesi hem de ölünce cehenneme girmesi Yüce Allah'ın merhamet ve adalet sıfatları ile de bağdaşmaz. Ayrıca gömülen kız, müşrik birinin çocuğu da olsa bulûğa ermediği için inanmak gibi bir sorumluluğu yoktur, küçük yaşta ölen çocukların yeri cennettir. ${ }^{34}$ Genel kabule göre de ölen her çocuk masumdur ve cennete girecektir." şeklinde özetlemek mümkündür. ${ }^{35}$

Bize göre İslâm'ın temel ilkelerine muhalif bir anlam içeren bu hadisin Kütüb-i sitte içinde yer alması bazı âlimleri yukarıda zikredilen te'villeri yapmaya zorlamıştır. Ancak yapılan bu te'viller ve izahlar ikna edici bulunmadığı için güncel yeni izahlara ihtiyaç duyulmaktadır. Söz konusu hadis hakkında "anlaşılması zordur" diyerek yeni bir yaklaşım sergileyen Yavuz Köktaş hadiste geçen "mev'ûdetün" kelimesine "gömülen kı" değil de "kızını gömdürten kadın" anlamının verilmesinin daha uygun olacağını çünkü metinde geçen bazı kelimelerin raviler tarafından hazfedilme ihtimali bulunduğunu dile getirmiştir. ${ }^{36}$ Yukarıda Tîbî'nin görüşü olarak da kaydettiğimiz bu yaklaşım zorlama bir yorum gibi görünse de en makul ve vakıaya uygun izahlardan biridir. Fakat üzerinde ittifak sağlanmış bir yorum değildir.

Sonuç olarak; ve'd konusunda, kiminin zayıf, kiminin münker dediği mezkûr rivayeti uzun uzun tartışmak yerine Kur'an ayetleri ve İslam'ın temel prensipleri ile uyumlu sahih ve sabit olan haberlere yönelmenin daha faydalı olacağı anlaşılmıştır. Sahih ve sabit olan bu haberlere göre; cahiliye döneminde ve'd geleneğinin yaygın olduğu, İslamiyet ile birlikte bu çirkin âdetin ortadan kalktığı, bu suçu işleyenlerin sorguya çekileceği, diri diri gömülen kız çocuklarının ise cennette olacağı açık ve seçik olarak bildirilmiştir.

Konumuzla ilgili olarak دفن البنات من المكرمات lafızları ile nakledilen haber de anlamındaki garabetten dolayı ciddi tartışmalara yol açmıştır.

34 Bu konuda şaz görüşler de vardır. Örneğin Haricilerin Ezrâkiler kolu gibi bazı aşırı gruplar ölen müşrik çocuklarının cehennemde olacağını savunmuşlardır. Geniş bilgi için bkz., Adnan Demircan, “Cahiliye Araplarında Kız Çocuklarını Gömerek Öldürme Adeti", ISSTEM, İslâm San'at, Tarih, Edebiyat ve Mûsikîsi Dergisi, 2/3 (2004): 930.

35 Ebu Abdillah Ubeydullah b. Muhammed b. Muhamed el Hemdan el-Akberi İbn Batta (ö. 387/998), el-İbânetü'l-kübra (Riyad: Dâru'r-Râye, 1994), 4: 74.

36 Yavuz Köktaş, Günümüz Hadis Problemleri (İstanbul: İnsan Yayınları, 2014), 81. 
184 | Orhan YILMAZ

Hadis külliyatı içerisinde yer almayan bu rivayetin cahiliye döneminde kız çocuklarını gömmenin güzel bir davranış olduğunu anlatmak için kullanıldığ 1 ifade edilmiştir. ${ }^{37}$

Araştırmalarımıza göre Taberâni'nin İbn Abbas'tan tek tarik ile naklettiği rivayetin aslı الحمد لله دفن البنات من المكرمات şeklindedir. Bu lafızlarla gelen haberin vürûd sebebi dikkate alındığında mezkûr rivayetin kızların diri diri gömülmesi ile alakalı olmadığı anlaşılmaktadır. ${ }^{38}$ Bir rivayete göre kızı Rukiyye (ö. 2/624) vefat edince Hz. Peygamber onu defnetmiş ve taziyeye gelenlere bu sözü söylemiştir. ${ }^{39} \mathrm{~Hz}$. Peygamber'in taziyeye gelen insanlara bu sözü niçin söylediği kesin olarak bilinmemektedir. Ancak öyle anlaşılıyor ki merhamet ve şefkat Peygamberi Hz. Muhammed (sav) kızı Rukiye'nin ölüm acısını yüreğinde hissedip bir baba olarak ona karşı son görevini yerine getirmiş, onu kendi elleri ile defnederek farklı bir davranış sergilemiştir. Orada bulunan insanların bu davranışından dolayı kendisini yadırgayacaklarını düşünerek Hz. Peygamber bu davranışının güzel bir sünnet olduğunu ifade etme ihtiyacı duymuş ve الحمد لله دفن البنات من المكرمات buyurmuştur. Yani Allah'ın takdiri ile vefat eden kızını kendi elleri ile defnetmek sûretiyle Hz. Peygamber, kızlara değer verdiğini göstermek istemiştir.

Cahiliye döneminde yaşayan herkesin "ve'dü'l-benât" olayına sıcak baktığı, bu suçu işlediği veya onayladığı iddia edilmez. O dönemde kız çocuklarını öldürme âdetini hoş karşılamayan, bu kötü davranışa karşı mücadele edenlerin olduğu da bilinmektedir. Bir rivayete göre, Câhiliye döneminin önemli şairlerinden Temim kabilesine mensup Ferezdak'ın (ö. 115/733) dedesi Sa'sa b. Nâciye el-Mücâşî (ö. 9/630) Allah Rasûlü'ne cahiliye döneminde her bir kız çocuğu için iki deve vererek 360 çocuğu kurtardığını, bu ameli için kendisine verilecek bir sevabın olup olmadığını sormuştur. Hz. Peygamber bu hayırlı işine karşılık Yüce Allah'ın kendisini İslâm nimetine kavuşturduğunu ifade etmiştir. ${ }^{40}$

37 Demircan, "Cahiliye Araplarında Kız Çocuklarını Gömerek Öldürme Âdeti", 16; Mehmet Altuntaş, "Câhiliye Dönemi Evlilikleri ve Muallaka Şiirlerinde Anlatılan Hayatın Kur'ân Açısından Değerlendirilmesi”, Turkish Studies, 11/ 5 (2016): 51.

38 Süleyman b. Ahmed b. Eyyub ebu'l-Kâsım et-Taberâni, el-Mu'cemu'l-kebir, thk. Hamdi b. Abdi'l-Mecid es-Selefî (Musul: Mektebetü'l-'ulûm ve'l-hikme, 1993) 11: 366.

39 Müttaki, Kenzu'l-'ummâl, 3: 287.

40 Elmalılı M. Hamdi Yazır, Hak Dini Kur'ân Dili (İstanbul: Azim Yayınları, 1992), 9: 20; Mevdûdi, Tefhîmu'l-Kurân, 7: 48. 
Bu çirkin âdetin ne zaman başladığına dair çeşitli görüşler ortaya atılmıştır. Bazı tarihçilere göre Ve'dü'l-benât âdeti İslâm'ın zuhuruna yakın bir zamanda başlamış ve sadece bazı göçebe kabileler arasında yaygınlık kazanmıştır. ${ }^{41}$ Anlatıldığına göre bir savaşta Temim kabilesinin malları ganimet, kadınları ise cariye olarak alınır. Yapılan bir antlaşma ile kabilenin tüm kızları geri döner, fakat Kays b. Asım'ın kızı kendisini esir alan efendisine âşık olur ve onun yanında kalmayı tercih eder. Bu durum babasının çok zoruna gider ve bundan sonra doğacak her kızını öldürmeye yemin eder. Kays b. Asım yeminini yerine getirmek için doğan pek çok kızını öldürür. Böylece ve'dü'l-benât geleneği başlamış olur. ${ }^{42}$ Kays b. Asım gibi bazı zatların Müslüman olduktan sonra Hz. Peygamber'e gelip cahiliye döneminde kızlarını öldürdüklerini haber vermeleri ile bu çirkin âdetin İslâm'ın zuhuruna yakın zamanda ortaya çıktığı düşünülmüş olabilir. Ancak bu tespitin doğru olmadığı, ve'dü'lbenât suçunun çok daha eskilere dayandığını söyleyenler de vardır. ${ }^{43}$

Daha önce de ifade edildiği gibi cahiliye döneminde fiziksel olarak zayıf ve bakıma muhtaç olmaları, büyüyünce kötü yola düşme endişesi, savaş ve baskınlarda esir alınarak pazarlarda satılma riski gibi gerekçelerle kı çocukları istenmezdi. Kızı dünyaya gelen babalar toplumda kınanır, anneler ise kız doğurduğu için utanırdı. Kızlarının cariye olarak alınıp satılması namusuna düşkün cahiliye Arapları için oldukça onur kırıcı ve utanç verici bir durum olarak algılanırdı. Kız çocuklarının bu fizyolojik ve sosyolojik durumu cahiliye Araplarına göre onların yok edilmesini gerektirecek kadar rahatsızlık verecek boyuttaydı.

Rivayetlerden anlaşıldığına göre cahiliye döneminde kız çocuklarının insan evladı olduğu unutulmuş, bir yavruya karşı gösterilmesi gereken şefkat ve merhamet yerini acımasızlığa ve merhametsizliğe bırakmıştır. Böyle bir ortamda insani ölçülerin yeniden inşasına ve yaratılana karşı merhamet ve şefkat duygularının yeniden ihyasına ihtiyaç duyulmaktaydı. İslâm'ın zuhuru ile birlikte insani duygular kalplere ve zihinlere yerleşince ve'dü'l benâtın ne derece çirkin bir eylem olduğu anlaşılmış ve bu ahlak dışı gelenek en hızlı şekilde terk edilmiştir. Kız çocuklarına yönelik sergilenen bu gayri insani tutum,

41 Demircan, “Cahiliye Araplarında Kız Çocuklarını Gömerek Öldürme Âdeti”, 18, 19.

42 Şemsettin Günaltay, İslâm Öncesi Araplar ve Dinleri (Ankara: Ankara Okulu Yayınları, 2013), 120.

43 Tartışmalar için bkz. Demircan, “Cahiliye Araplarında Kız Çocuklarını Gömerek Öldürme Âdeti", 20. 
186 | Orhan YILMAZ

cahiliye döneminin bir sembolü olarak kıyamete kadar hafızalardaki yerini koruyacaktır. Ayrıca Mev'ûde (diri diri gömülen kız çocuğu) ile alakalı ayetler ve yukarıda zikrettiğimiz rivayetler gösteriyor ki cahiliye döneminde kız çocuklarının öldürülmesi nadirattan olan bir durum değildir. Eğer öyle olsaydı, bu durum ayetlere, hadislere ve tarihi sözleşmelere konu olmazdı.

\section{II- Hz. Peygamber Döneminde Kız Çocuklarına Verilen Değer}

İslamiyet'in zuhuru ile birlikte, kız çocuklarını değersiz, hor ve hakir gören cahiliye anlayışı şiddetle kınanmış, onlara şefkat ve merhametle muamele edilmesi telkin ve tavsiye edilmiştir. $\mathrm{Hz}$. Peygamber'in bu konudaki uygulamaları ise söz konusu tavsiye ve telkinlerin nasıl pratize edileceğini ortaya koyan canlı örnekler olmuştur.

Konu ile ilgili birkaç ayet zikredildikten sonra Hz. Peygamber'in kız çocuklarına yönelik örneklik teşkil eden davranışları üzerinde durulacaktır.

\section{a- Ayetlerde Kız Çocuklarına Verilen Değer}

Bilindiği üzere İslâm dini getirdiği kural ve kaidelerle cinsiyetten kaynaklanan imtiyaza son vermiş ve üstünlügü takva kriterine bağlamıştır. "Ey insanlar! Şüphe yok ki, biz sizi bir erkek ve bir dişiden yarattık ve birbirinizi tanımanız için sizi boy ve kabilelere ayırdık. Allah katında en değerli olanınız ona karşı gelmekten en çok sakınanınızdır." 44 ifadeleri ile bu gerçek dile getirilmiştir.

Ayetlerde kız veya erkek çocuk sahibi olan ebeveynin daha üstün olduğuna dair bir bilgiye de yer verilmemiştir. Şura sûresinin 49 ve 50 . ayetlerinde Yüce Allah; "Göklerin ve yerin egemenliği Allah'a aittir. O dilediğini yaratır; dilediğine kız çocukları, dilediğine de erkek çocukları verir. Yahut erkek ve kız çocukların birlikte verir. Dilediğini de çocuksuz bırakır." buyurmak sûretiyle kız veya erkek çocuk yaratma tasarrufunun kendi elinde bulunduğunu bildirmiş ve kişinin sahip olduğu evladın takdir-i ilahi ile belirlendiğini bilip buna rıza göstermesinin gerektiğini vurgulamıştır.

\section{b- Hz. Peygamber'in Kızlarına Verdiği Değer}

Cahiliye dönemindeki anlayışın tam aksine İslâm dini kız çocuklarına karşı şefkat ve merhametli olunmasını tavsiye etmiştir. Hz. Peygamber bırakın diri diri gömülmesine, kız çocuklarının en küçük bir

\footnotetext{
44 Hucurât 49/13.
} 
haksızlığa uğrayıp aşağılanmasına bile müsaade etmemiş, onlara en iyi şekilde muamele edilmesini tavsiye etmiştir. ${ }^{45}$ Hatta $o$ cahiliye döneminde zulme uğramış, yaşama hakkı elinden alınmış olan mev'ûdeyi cennetle müjdeleyerek onlara iade-i itibarda bulunmuştur. İbn Ebî Şeybe (ö. 235/850) ve Ebu Dâvud'un (ö. 275/889) naklettiği bir rivayete göre Hz. Peygamber'e kimlerin cennete gideceği sorulmuş o; "Nebiler cennettedir, şehitler cennettedir, diri diri gömülen kız çocukları cennettedir" ${ }^{\prime 6}$ buyurmak sûretiyle mev' ûdeyi cennetle müjdelemiştir. ${ }^{47}$

Aşağıda zikredilen örneklerden anlaşıldığına göre, kız çocuklarının kıymetini artırmak ve onlara iyi muamele edilmesini sağlamak için $\mathrm{Hz}$. Peygamber her firsatta ashabına kendi kız çocuklarına yahut kimsesiz kız çocuklarına bakmalarını, onları erkek çocuklardan ayırmamalarını tavsiye etmiştir. Bir sahâbi kendi kızı veya başka birinin kızına iyilik yapmış ise Allah'ın elçisi o sahâbiye iltifatta bulunuş ve onu cennetle müjdelemiştir. Cahiliye dönemindeki "soyu erkek evlat sürdürür" anlayışının aksine dört kız babası olan Hz. Peygamber'in soyu kızları ile devam etmiştir.

Bilindiği üzere Hz. Hatice'nin vefatı ve ablalarının evlenip gitmesi ile Hz. Fâtıma uzun yıllar babası ile birlikte yaşamıştır. Daha sonra ablalarının ölümü ile yalnız kalan Hz. Fâtıma Hz. Peygamber'in soyunu devam ettiren kızlarından biri olmuştur. Hadis külliyatı içerisinde Hz. Peygamber'in Hz. Fâtıma'ya nasıl hürmet ettiği, onu nasıl sevip saygı gösterdiğine dair pek çok örnek mevcuttur. Hz. Aişe'nin bildirdiğine göre, sözünde ve sohbetinde Hz. Peygamber'e en çok benzeyen kişi Fâtıma'dır. Hz. Fâtıma babasının odasına girdiğinde Hz. Peygamber'in onu ayakta karşıladığı, selamını alıp onu öptüğü ve yerine oturttuğu, babası da Fâtıma'yı ziyaret ettiğinde Fâtıma'nın aynı davranışı sergilediği nakledilmiştir. ${ }^{48}$

45 Geniş bilgi için bkz., Zülfikar Durmuş, "Hz. Peygamber'in Kızlarıyla Olan İletişimi”, Diyanet İlmi Dergi, 45/1 (2009).

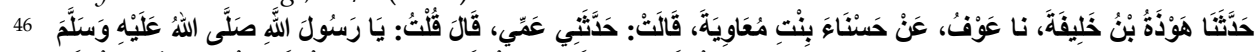
مأنَn Ebî Şeybe, Kitâbu'l-Musannef, thk. Kemal Yusuf (Riyad: Mektebetü'r-rüşt, 1409), 4: 224; Ebu Davud, Cihad, 27.

$47 \quad$ Ahmed b. Hanbel, Müsned, 34: 192.

48 Muhammed b. İsmâil el-Buhari, el-Edebü'l-müfred, thk. Muhammed Fuad Abdu'l-Bâki (Beyrut: Dâru'l-Beşâiri'l-İslâmiyye, 1989), 337; Müslim, Fadâilu's-sahâbe, 15; Ebu Abdillah Muhammed İbn Sa'd, et-Tabakâtu'l-kübra (Beyrut: Dâru Sâdır, 1985), 8: 26. 
Hz. Peygamber'in kızlarına karşı nasıl merhamet sahibi olduğunu gösteren bir başka örnek kızı Rukiyye'nin vefatı esnasında yaşanmıştır. Bedir savaşından döndüğünde (Ramazan, Mart 624) Rukiyye'nin vefat ettiğini öğrenen Hz. Peygamber, kızı Fâtıma ile birlikte Rukiyye'nin mezarını ziyarete gider. Kızı Rukiyye'nin kabri başında ona dua ederken duygularına hâkim olamaz ve ağlamaya başlar. Hz. Fâtıma eteği ile babasının gözyaşlarını silip onu teselli eder. ${ }^{49}$

Baba olarak Hz. Peygamber'in kızı Zeynep'le olan ilişkisi örneklik açısından oldukça önemlidir. Hz. Peygamber miladi 622 tarihinde Mekke'den Medine'ye hicret ettiğinde, en büyük kızı Hz. Zeynep (ö. 8/ 630) Ebu'l-As b. Rebi ile evli olduğu için babasıyla hicret edemeyip, Mekke'de kalmıştı. Zeynep'in kocası Ebu'l-As müşriklerin safında Bedir savaşına katılmış ve Müslümanlara esir düşmüştü. Zeynep kocasını kurtarmak için annesi Hz. Hatice'nin kendisine düğün hediyesi olarak verdiği gerdanlığı fidye olarak göndermişti. Hz. Peygamber alınan ganimetler arasında bu gerdanlığı görünce çok duygulanmış, iki yıldır görmediği kızı Zeynep'e olan özlemi daha da artmıştı. Zeynep'i Medine'ye gönderme şartı ile Ebu'l-As'1 serbest bırakmış, kızının gönderdiği fidyeyi de iade etmişti. Ebu'l-As Mekke'ye dönünce sözünü tutmuş, kardeşi Kinâne ve Zeyd b. Hârise ile Zeynep'i Medine'ye göndermişti. Bu durumu kabullenmeyen müşriklerden Hebbar b. elEsved yollarını kesmiş, hamile olan $\mathrm{Hz}$. Zeynep'i binitinden düşürüp onun düşük yapmasına neden olmuştu. Tekrar evine dönen Zeynep birkaç gün istirahat edip iyileşince tekrar yola çıkmış ve Medine'ye ulaşmıştı. Kızına saldırı olayını öğrenen Hz. Peygamber bir birlik hazırlayıp Mekke'ye göndermiş, fakat bu birlik Hebbar ve adamlarını yakalayamadan dönmüştü. ${ }^{50}$

Ebu'l-As hicretin yedinci yılında Müslüman olup Medine'ye hicret edince Zeynep ile yeniden evlenmişti. Fakat bu evlilik uzun sürmemiş yaklaşık bir yıl sonra, Zeynep vefat etmişti. ${ }^{51} \mathrm{~Hz}$. Peygamber kızının techiz ve tekfin işleri ile bizzat ilgilenmiş, kendi elbisesinden bir parçayı kızına iç gömlek yapmıştı. Cenaze namazını kıldırdıktan sonra onu, damadı Ebu'l-As ile birlikte defnetmiş, sonra da kızının kabri başında oturup ağlamışt. ${ }^{52}$

49 İbn Sa'd, et-Tabakâtu'l-kübra, 8: 37.

50 İbn S'ad, et-Tabakâtu'l-kübra, 8: 31.

51 İbn Sa'd, et-Tabakâtu'l-kübra, 8: 34.

52 Buhari, Cenâiz, 71 
Tarihçiler ve hadisçilerin rivayet ettiği haberlere göre $\mathrm{Hz}$. Peygamber kızlarına gösterdiği sevgiyi kız torunlarına da göstermiştir. Hz. Zeynep Medine'ye taşınınca Ümâme isimli kızı ile birlikte Hz. Peygamber'in evine yerleşir. Hz. Peygamber, kızı ve küçük yaştaki torunu Ümâme'nin Medine'ye göç etmelerine çok sevinir ve onlarla zaman geçirmeye başlar. Torunu Ümâme ile birlikte toplumun içine çıkar, mescide gider ve namaz kılar. Bir rivayete göre Hz. Peygamber Ümâme kucağında olduğu halde ashabına namaz bile kıldırmıştır. Secdeye varırken Ümâme'yi yere biraktığı, kıyama kalkınca onu tekrar kucağına alarak namaza devam ettiği rivayet edilmiştir. ${ }^{53}$ Söz konusu rivayeti şerh eden Aynî (ö. 855/1452) fiille izahın sözden daha kuvvetli olduğunu söyleyerek Hz. Peygamber'in bu davranışı ile kız çocuklarına yönelik negatif tutumu değiştirmek istediğini ifade etmiştir. ${ }^{54}$ Tecrîd-i Sarih mütercimi Ahmet Naim (ö. 1934) de aynı hususa dikkat çekmiş, Hz. Peygamber'in kız torunu Ümâme kucağında olduğu halde namaz kıldırmasının hikmetini şu ifadelerle açıklamıştır: “Ümame’nin namazda iken omuzda taşınmasındaki sır, kızları sevmemek, taşımalarından ibâ etmek gibi Arab'ın cahiliyetten kalma âdâtı mekrûhelerini hükmen iptaldir. Bu manasız ibâ ve istikbârı reddetmekte mübalağa olsun diye namazda bile omuza alınabileceklerini bilfiil göstermiş oldular ki, fiil ile beyan kavl ile beyandan elbette akvâdır." 55 Yani Hz. Peygamber namaz gibi önemli bir ibadet esnasında, bir kız çocuğunu kucağında taşıyarak toplumun bu konudaki algısını müspet yönde değiştirmek istemiştir.

Hz. Peygamber sadece dışarıdaki insanlara değil kendi aile bireylerine karşı da kız çocuklarının değerini artırmaya yönelik davranışlar sergilemiştir. Hz. Âişe' den gelen bir rivayete göre kendisine bir gerdanlık hediye edilen Rasûlullah bunu ailesinden en çok sevdiği kişiye vereceğini söyler. Orada bulunan diğer eşleri gerdanlığın Hz.

53 Buhari, Sala, 106; Müslim, Mesâcid, 9; Ebu Dâvud, Sala, 171; Ahmed b. Hanbel, Müsned, 5: 295; Dârimi, Sala, 2: 858.

54 Bedruddin Ebu Muhammed Mahmud b. Ahmed Aynî, 'Umdetu'l-kâri şerhu Sahîhi'lBuhâri (Beyrut: Dâru'I-kitâbi'l-ilmiyye, 2001), 5: 440.

55 Ahmed Naim, Sahîhi Buhâri Muhtasarı Tecrid-i Sârih Terceme ve Şerhi (Ankara: Diyanet İşleri Başkanlığı Yayınları, 1983), 2: 458. 
190 | Orhan YILMAZ

Âişe'ye verileceğini düşünürken Rasûl-i Ekrem Ümâme'yi çağırarak gerdanlığı onun boynuna takar..$^{56}$

\section{c- Hz. Peygamber'in Cennetle Müjdelediği Babalar}

Hz. Peygamber kız çocukları konusunda sünnete uygun davranan babaları ve bakıma muhtaç kız çocuklarını himaye eden ümmetini cennetle müjdelemiştir. Ebu Said el-Hudrî'nin naklettiğine göre Allah'in Rasûlü şöyle buyurmuştur; "Kimin üç kızı veya üç kız kardeşi veyahut da iki kızı veya iki kız kardeşi olup da geçimlerini sağlar, onlar hakkında Allah'tan korkarsa, o kişi için cennet vardır." 57

Benzeri bir haber yine Ebu Sâid el-Hudrî'den faklı lafızlarla nakledilmiştir. Râvilerin sika olduğu söylenen bu makbul hadiste Hz. Peygamber şöyle buyurmuştur; "Kim ki üç kız çocuğu yetiştirir, güzel terbiye eder, evlendirir ve onlara iyilikte bulunursa, o kişi için cennet vardır."(من عال ثلاث بنات فأدبهن وزوجهن وأحسن إليهن فله الجنة) Bu hadisin şerhinde; "Bakılması tavsiye edilen üç kız çocuğunun kişinin kendi öz evladı olabileceği gibi başka çocukların olabileceği de ifade edilmiştir.

Hz. Aişe'nin (ö. 58/678) anlattığına göre bir fakir kadın kucağında iki kız çocuğu ile Hz. Aişe'nin yanına gelir. Hz. Aişe bunlara üç hurma ikram eder. Kadın her çocuğuna bir hurma verir. Çocuklar hurmalarını yiyince anneleri kendi hurmasını da onlara paylaştırır. Bu durum $\mathrm{Hz}$. Aişe'nin çok hoşuna gider ve şahit olduğu bu olayı Hz. Peygamber'e anlatır. Allah Rasûlü bu kadın hakkında; "Allah bu yaptığından dolayı o kadına cenneti vacip kılmıştır." buyurur. ${ }^{59}$ Rivayetin başka bir varyantında Hz. Aişe çocukları ile birlikte yanına gelen bu kadına tek hurma verir. Kadın hurmayı iki çocuğu arasında paylaştırır. Hz. Aişe bu durumu Hz. Peygamber'e bildirince o; "Kim kızları ile imtihan edilir de onlara karşı güzel davranışlar sergilerse o kızlar onunla cehennem

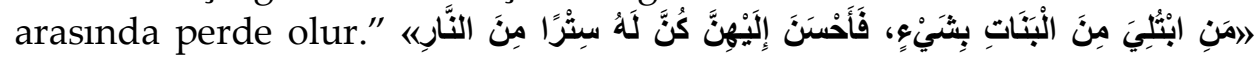

56 Ebu Dâvud, Hatem, 8; Rivayeti değerlendiren Şuayb Arnavut, Ali b. Zeyd ve Ümmü Muhammed isimli raviler sebebiyle bu haberin zayıf olduğunu söylemiştir. Bkz. Ahmed b. Hanbel, Müsned, 6: 101.

57 Ebu İsa Muhammed b. İsa et-Tirmîzi, Sünen (İstanbul: Çağrı Yayınları, 1981), Birr, 13.

58 Ebu Dâvud, Edeb, 131.

59 Müslim, Birr, 46; Ahmed b. Hanbel, Müsned, 41: 159; Tirmizi, Birr, 13. 
buyurur. ${ }^{60}$ Aynı rivayeti farklı lafızlarla nakleden Tirmizi bu haberin hasen olduğunu söylemiştir. ${ }^{61}$

Ebu Hureyre'den (ö. 58/678) gelen ve muhakkik tarafından sahih olduğu bildirilen bir başka rivayete göre ise Hz. Peygamber; "Kimin üç kızı olur ve bu çocuklardan dolayı sıkıntıya düşer de bu sıkıntıya sabrederse sadece kızlarına iyi muamele ettiğinden dolayı cennete girer" buyurunca bu güzel müjdeyi duyan sahâbeden biri; "Ya iki kız olursa?" diye sorar. Hz. Peygamber aynı müjdenin iki kızı olan için de geçerli olduğunu söyler. Bir başka şahıs tek kızı olanın durumunu sorar. Allah Rasûlü tek kızı olana da aynı mükâfatın verileceğini bildirir. ${ }^{62}$

Rivayetin İbn Abbas (ö. 68/688) tariki ile gelen varyantında $\mathrm{Hz}$. Peygamber, iki kız sahibi olup ta onlara güzel muamele edenleri cennetle müjdelemiştir.63 İsnad yönü ile zayıf olduğu bildirilen bu hadis, şahitlerinin desteği ile hasen derecesine yükselmiş bir haberdir. ${ }^{64}$

Yukarıda geçtiği üzere kişinin kendi soyundan olmayan bakıma muhtaç kız çocuklarına iyi muamele etmesi, onların bakımını üstlenmesi tavsiye edilmiştir. ${ }^{65}$ Enes b. Malik'ten (ö. 93/712) gelen bir rivayete göre Hz. Peygamber; "Her kim iki kız çocuğun bakımını üstlenir, onları büyütürse ben ve o kıyamette şöyle olacağız" buyurmuştur. ${ }^{66}$ Aynı rivayeti nakleden İbn Ebî Şeybe (ö. 235/850) ve İbn Hibbân (ö. 354/965) Hz. Peygamber'in iki parmağını birleştirerek “...ben ve o şöyle olacağız" dediğini kaydetmişlerdir. ${ }^{67}$ Benzeri bir rivayet Tirmîzî tarafından da kaydedilmiştir. ${ }^{68}$

Ahmed b. Hanbel'in kaydettiği bir rivayette ise Hz. Peygamber; "Her kim iki kız evlat yahut üç kız evlat yahut iki kız kardeş yahut üç kız kardeşe, onlar kendi yuvasını kuruncaya veya ölünceye kadar bakarsa

60 Müslim, Birr, 46.

61 Tirmizî, Birr, 13.

62 Ebu Abdillah el-Hâkim en-Nisâbûrî, el-Müstedrak 'ala's-sahîhayn, thk. Mustaf Abdu'lKadir Ata (Beyrut: Dâru'l-kütübi'l-'ilmiyye, 1990), 4: 195.

63 "إbn Hibban, Sahîh, 7: 207.

64 Bkz. İbn Ebi Şeybe, Musannef, 8: 551, Ahmed b. Hanbel, Müsned, 1: 235, 236; Hâkim, Müstedrak, 4: 178.

65 Geniş bilgi için bkz., Saffet Sancaklı, “Hz. Peygamber'in Çocuklara Verdiği Değer Bağlamında Sokak Çocukları Sorununa Genel Bir Bakış", Selçuk Üniversitesi İlahiyat Fakültesi Dergisi, 21 (2016): 24.

66 Müslim, Birr, 46,

67 İbn Ebi Şeybe, Musannef, 8: 364; İbn Hibbân, Sahîh, 2: 191.

68 Tirmizi, Birr, 13. 
ben ve o şöyle olacağı" diyerek orta parmak ile işaret parmağını birleştirip ashabına göstermiştir. ${ }^{69}$ Ukbe b. Amir'in sema yolu ile naklettiği bir başka rivayette bakımları üstlenilen, ihtiyaçları karşılanan ve kendilerine güzel muamele edilen üç kız çocuğunun cehennem ateşi ile bakımlarını üstlenen şahıs arasında perde olacakları bildirilmiştir. ${ }^{70}$

Görüldüğü üzere pek çok hadiste ister evlat, ister kardeş, isterse başkasına ait olsun kız çocuklarına karşı iyi muamele edilmesi, onların bakımlarının sağlanması tavsiye edilmekte ve bu tavsiyelere uyanlar cennetle müjdelenmektedir.

Hz. Peygamber'in bu müjdesine nail olmak isteyen bazı sahabi örneklerine rastlamaktayız. Vâkıdî́nin (ö. 207/822) bildirdiğine göre Hz. Peygamber kaza umresini yapıp Mekke'den ayrılacağı zaman Hz. Hamza'nın (ö. 2/624) Selma binti Umeys'ten (ö. 65/685) olma kız Ümâme de Hz. Peygamber ile birlikte Medine'ye gitmek ister. Bu talebi kabul görünce Ümâme Hz. Ali'nin ailesi ile birlikte Medine'ye ulaşır. Babası Uhut savaşında şehit olan, annesi ise başka biriyle evlenip Mekke'de kalmayı tercih eden altı yedi yaşlarındaki bu çocuğun Medine'de kimin evinde kalacağı hususu tartışılır. Zeyd b. Hârise (ö. 8/630), Hz. Ca'fer b. Ebî Tâlib (ö. 8/630) ve Hz. Ali (ö. 35/656) kızın bakımını üstlenmek isterler. Zeyd b. Hârise; "Ben ona bakmaya daha çok hak sahibiyim. Çünkü o benim kardeşimin kızıdır. Hz. Peygamber ben ve Ümâme'nin babasını uhuvvet antlaşmasında kardeş ilan etti." der. Hz. Ca'fer de amcasının kızını himaye etmek ister ve gerekçesini şu şekilde ifade eder: "Onun teyzesi Esma bnt. Umeys benim eşimdir. Öyle ise ben Ümâme'ye bakmaya daha çok hak sahibiyim". Söz hakkı isteyen Hz. Ali; “Onu Mekke'de müşrikler arasında bulup Medine'ye getiren benim. Soyca da ona yakınım. Onun bakımını üstlenmek benim hakkımdır." der. Hz. Peygamber Ümâme'nin bakımını üstlenmek isteyen bu üç sahâbeye iltifatta bulunur, onları farklı özelliklerinden dolayı öven ifadeler kullandıktan sonra kararını bildirir. Cafer'in hanımı Esma bnt. Umeys

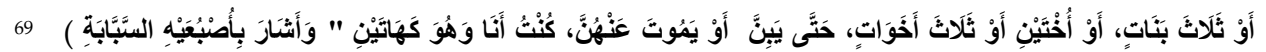

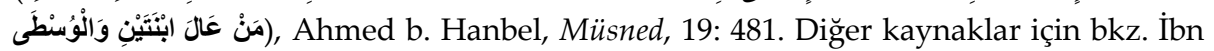
Ebi Şeybe, Musannef, 8: 552. Benzeri rivayetler için bkz. Ebu Dâvud, Edeb, 131; Ahmed b. Hanbel, Müsned, 3: 97.

70 Ebû Abdillah Muhammed b. Yezid el-Kazvînî İbn Mace, Sünen (İstanbul: Çağrı Yayınları, 1981), Edeb, 3. 
kızın teyzesi olduğu için Hz. Peygamber Ümâme'nin bakımını Cafer'e verir. Hz. Cafer bu duruma çok sevinir. ${ }^{71}$

Son zamanlarda gerek boşanmalar nedeniyle, gerekse ülkemize akın eden mültecilerden dolayı olsun bakıma muhtaç çocuk sayısı hızla artmıştır. Bu çocukların büyük bölümü devlet eli ile "Çocuk Bakım Evleri" ve "Sevgi Evleri" gibi resmi kurumlar yanında çadır evlerde barınmaktadırlar. İstatistiklere göre resmi kurumlarda barınan çocukların sadece \% 4'ü koruyucu aileler tarafından alınıp aile ortamında yetiştirilmektedirler. ${ }^{72} \mathrm{Bu}$ rakamın bu kadar düşük olmasının en önemli sebebi toplumun ilgisizliği ve çocuk seçme tercihindeki ısrar ile açıklanmıştır. Yani aileler küçük yaşta olan çocuklara koruyucu aile olmak istemekteler veya cinsiyet tercihinde israr etmektedirler. ${ }^{73}$ Bazı muhafazakâr aileler ise ileride büyüyüp mahrem olacağını düşünerek yani dini gerekçelerle evlat edinmek veya koruyucu aile olmak istememektedirler. ${ }^{74}$

Aslında hali vakti yerinde ailelerin koruyucu aile sıfatı ile bir, iki veya üç kız çocuğunu yuvadan alıp bakımlarını üstlenmesi, yetiştirip topluma kazandırması, yukarıda geçen hadislerde Hz. Peygamber'in ümmetine tavsiye ettiği ve sahibini cennetle müjdelediği sâlih amel türünden bir davranış olarak algılanmaktadır. Bilindiği gibi $\mathrm{Hz}$. Peygamber Zeyd b. Hârise ve Hz. Ali'yi kendi evinde kendi evladı gibi büyütmüş ve her ikisini de zamanı gelince evlendirip yuva sahibi yapmış

71 Ebu Abdillah Muhammed b. Amr b. Vâkidi, Kitabu'l-me ğâzi, thk. Marsden Jones (Beyrut: Alemu'l-kütüb, 1966), 2: 739; Buhari, Meğâzi 43; Ebu Dâvud, Talak, 34; Geniş bilgi için bkz. Ayşe Esra Şahyar, "Ümâme bint Hamza", Türkiye Diyanet Vakfı İslam Ansiklopedisi (Ankara: TDV Yayınları, 2012), 42: 301-302.

72 Muammer Salim, “Geçmişten Günümüze Türkiye'de Çocuk Koruma Politikaları ve Sosyal Hizmetler ve Çocuk Esirgeme Kurumu" (Yüksek Lisans tezi, Süleyman Demirel Üniversitesi Sosyal Bilimler Enstitüsü, 2011), 93.

73 Salim, "Geçmişten Günümüze Türkiye'de Çocuk Koruma Politikaları ve Sosyal Hizmetler ve Çocuk Esirgeme Kurumu", 92.

74 Yani evlatlık edinmek caiz olmadığı için Müslüman aileler bakıma muhtaç çocukları evlerinde barındırmak istememektedirler. Oysa Kur'ân'1 Kerîm'de yasak edilen kişinin kendi sulbünden olmayan bir çocuğu kendine evlat edinip onu kendine mirasçısı kılmasıdır. Ahzab 33/4, 5, Geniş bilgi için bkz. İbrahim Acar, "İslâm Hukuku Açısından Evlat Edinme ve Hz. Peygamber'in Zeynep'le Evliliği”, İslâm Hukuku Araştırmaları Dergisi, 7 (2006): 99-110. 
194 | Orhan YILMAZ

bir aile reisidir. ${ }^{75}$ Eğer büyüyünce ev halkına mahrem olur gerekçesi ile bir çocuğun bakımını üstlenmek dinen sakıncalı görülseydi $\mathrm{Hz}$. Peygamber, Hz. Ali ve Zeyd b. Hârise'yi kendi evinde çocukları ile birlikte barındırmazdı. Ayrıca Osmanlı Devleti döneminde kimsesiz çocukların koruyucu aileler vasıtası ile yetiştirilip topluma kazandırıldığına dair örneklere de rastlamaktayız. ${ }^{76}$

\section{Sonuç}

Bir insanın hayatta sahip olabileceği en kıymetli varlığı çocuklarıdır. Yüce Allah insanlara rehber olsun diye gönderdiği kitabında bu gerçeğe dikkat çekmiş, evlatların önemi üzerinde durmuş, onların hayatın süsü ve saadeti olduğunu bildirmiştir. Evlatlardan bahseden ayetlerde kime kı kime oğlan çocuğu verileceği hususunun Yüce Allah'ın takdirinde oluğu ifade edilirken, erkeğin kıza veya kızın erkeğe üstün olduğuna dair açı bir ifade kullanılmamıştır. Söz konusu âyetlerde ve sahih hadislerde cahiliye dönemi Arap toplumunun gerek geçim sıkıntısı gerekse başka sebeplerle olsun kız çocuklarını hakir görmeleri hatta onları diri diri toprağa gömmeleri şiddetle kınanmış, haram kılınmış ve bu suçu işleyenlerin cezalandırılacakları bildirilmiştir.

Rivayetlere bakılırsa $\mathrm{Hz}$. Peygamber şefkat ve merhametle muamele etme, himaye, iyilik ve ihsanda bulunma bakımından cahiliye döneminin aksine kız çocuklarını erkeklere tercih etmiş gözükmektedir. Aynı zamanda dört kız babası olan Allah'ın Rasûl'ü onlara şefkat ve merhametle muamele edilmesi konusunda ümmetine tavsiye ve telkinlerde bulunmuştur. Ayrıca o, kendi kızlarına karşı sergilediği en güzel davranışlar ile ümmetine örnek olmuştur. Allah'ın elçisi özellikle de kimsesiz çocukları koruyup kollamayı, onları sevindirmeyi ve bakımlarını üstlenmeyi çok önemsemiştir.

Günümüzde Hz. Peygamber'in tavsiyelerini de dikkate alarak, imkânları müsait olan ailelerin, ister yakınları olsun isterse başkasına ait olsun, bakıma muhtaç kız çocuklarını yasalara uygun olarak ve mahremiyet sınırlarını da gözeterek evine alıp şefkat ve sevgi ile büyütmesi, eğitip topluma kazandırması dini bir görev olarak algilanmalıdır.

75 Geniş bilgi için bkz. Acar, "İslâm Hukuku Açısından Evlat Edinme ve Hz. Peygamber'in Zeynep'le Evliliği", 91.

76 Acar, “İslâm Hukuku Açısından Evlat Edinme ve Hz. Peygamber'in Zeynep'le Evliliği", 110. 


\section{Kaynakça}

Aba, Veli. "Kadınların Hukuki ve Sosyal Statülerine İlişkin Hadisler". Yüksek Lisans tezi, Erciyes Üniversitesi Sosyal Bilimler Enstitüsü, 2003.

Acar, İbrahim. "İslâm Hukuku Açısından Evlat Edinme ve Hz. Peygamber'in Zeynep'le Evliliği". İslâm Hukuku Araştırmaları Dergisi. 7 (2006): 99-110.

Ahmed b. Hanbel, Ebu Abdullah. el-Müsned. thk. Şuayb el-Arnavut. 45 cilt. Beyrut: Müessesetü'r-risâle, 2001.

Ahmed Naim. Sahîhi Buhâri Muhtasarı Tecrîd-i Sarih Terceme ve Şerhi. 12 cilt. Ankara: Diyanet İşleri Başkanlığı Yayınları, 1983.

Alâu'd-Dîn Ali b. Hüsamu'd-Din el-Muttakî. Kenzu'l-'ummâl fî süneni'lekvâl ve'l-ef'âl. Medine: Müessesetü'r-risâle, 1981.

Alûsî, Ebû'l-Fadl Şihabuddin es-Seyyid Mahmud. Rûhu'l-me'âni fi tefsîr'lKur'âni'l-'azîm ve's-seb'i'l-mesâni. 30 cilt. Beyrut: Dâru İhyâi'tTurasi'l-Arab, 1985.

Altuntaş, Mehmet. "Câhiliye Dönemi Evlilikleri ve Muallaka Şiirlerinde Anlatılan Hayatın Kur'ân Açısından Değerlendirilmesi". Turkish Studies. 11/5 (2016): 45-68.

Aynî, Bedruddin Ebu Muhammed Mahmud b. Ahmed. 'Umdetu'l-kâri şerhu Sahîhi'l-Buhâri. 25 cilt. Beyrut: Dâru'I-kitâbi'l-ilmiyye, 2001.

Azîmâbadi, Ebü't-Tayyib Muhammed Şemsü'l-Hak b. Emîr Alî edDiyânüvî el-Azîmâbâdî. 'Avnu'l-ma'bûd şerhu Süneni Ebî Dâvûd. 14 cilt. Beyrut: Dâru'l-kütübi'l-'ilmiyye, 1415.

Beğavî, Ebu Muhammed el-Huseyn b. Mes'ud. Tefsîru'l-beğavî. thk. Muhammed b. Abdillah el-Münir. 8 cilt. Riyad: Dâru Tayyibe, 1997.

Beyhâki, Ahmed b. Huseyn b. Ali b. Musa. es-Sünenü's-suğra. thk. Abdu'l-Mu'ti Emin Kal'acı. Pakistan: Câmi'âtu'd-Dirâsati'lİslâmiyye, 1989.

Beyhâki, Ahmed b. Huseyn b. Ali b. Musa. es-Sünenü'l-kübra. thk. 'Abdu'l-Kadir 'Ata. Beyrut: Dâru'l-kütübi'l-'ilmiyye, 2003.

Buhâri, Muhammed b. İsmâil. el-Edebü'l-müfred. thk. Muhammed Fuad Abdu'l-Bâki. Beyrut: Dâru'l-Beşâiri'l-İslâmiyye, 1989.

Buhâri, Muhammed b. İsmâil. el-Câmi'u's-sahîh. İstanbul: Akçağ Yayınları, 1981.

Canan, İbrahim. Peygamberimizin Sünnetinde Terbiye. İstanbul: Tuğra Yayınları, 1977. 
196 | Orhan YILMAZ

Dârimî, Ebu Muhammed Abdullah b. Abdurrahman. es-Sünen. thk. Hüseyin Selim. 4 cilt. Arabistan: Dâru'l-Muğni, 2000.

Demircan, Adnan. "Cahiliye Araplarında Kı Çocuklarını Gömerek Öldürme Adeti". ISTEM, İslâm San'at, Tarih, Edebiyat ve Mûsikîsi Dergisi. 2/3 (2004): 9-30.

Durmuş, Zülfikar. “Hz. Peygamber'in Kızlarıyla Olan İletişimi”. Diyanet İmi Dergi. 45/1 (2009): 75-90.

Ebu Dâvud, Süleyman b. Eş'as es-Sicistânî. Sünen. thk. Şuayb el-Arnavut. 7 cilt. Beyrut: Dâru Risâleti'l-Alemiyye, 2009.

European Commission. Strategy for equality between women and men 20102015. Belgium: Publications Office of the European Union, 2011.

Gülaçtı, Nurettin. "Sanatsal Bir Obje Olarak Kadın ve Bazı Toplumlarda Kadına Bakış". İdil, Sanat ve Dil Dergisi. 1/2 (2012): 83-89.

Günaltay, Şemsettin. İslâm Öncesi Araplar ve Dinleri. Ankara: Ankara Okulu Yayınları, 2013.

Hamidullah, Muhammed. İslâm Peygamberi. çev. Salih Tuğ. 2 cilt. Ankara: İmaj Yayınları, 2003.

İbn Batta, Ebu Abdillah Ubeydullah b. Muhammed b. Muhamed el Hemdan el 'Akberî. el-İbânetü'l-kübra. Riyad: Dâru'r-Râye, 2005.

İbn Ebi Şeybe, Ebu Bekir Abdillah b. Muhammed. el-Kitâbu'l-musannef. thk. Kemal Yusuf. 7 cilt. Riyad: Mektebetü'r-rüşt, 1409.

İbn Hibbân, Muhammed b. Hibbân. Sahîh-i ibn Hibbân bi tertîbi ibn Belban. thk. Şuayb Arnavut. 18 cilt. Beyrut: Müessesetü'r-risâle, 1993.

İbn Mâce, Ebû Abdillah Muhammed b. Yezid el-Kazvînî. es-Sünen. İstanbul: Çağrı Yayınları, 1981.

İbnü'1-Mülakkîn. el-Bedru'l-münîr. thk. Mustafa Ebu'1-Ğayz. 9 cilt. Riyad: Dâru'l-Hicre, 2004.

İbn Sa'd, Ebu Abdillah Muhammed. et-Tabakâtu'l-kübra. 9 cilt. Beyrut: Dâru Sâdır, 1985.

Kasapoğlu, Abdurrahman. “Kur'ân'a Göre Çocuklar Arasında Cinsiyet Ayrımcılığı". Fırat Üniversitesi Illahiyat Fakültesi Dergisi. 10/1 (2005): 75-96.

Kaymaz, İhsan Şerif. "Çağdaş Uygarlığın Mihenk Taşı: Türkiye'de Kadının Toplumsal Konumu”. Atatürk Yolu Dergisi. 12/46 (2010): 333-366.

Köktaş, Yavuz. Günümüz Hadis Problemleri. 3. bs. İstanbul: İnsan Yayınları, 2014. 
Mevdudî, Ebu'l-A'lâ. Tefhîmu'l-Kur'ân. çev. Komisyon. İstanbul: İnsan Yayınları, 1986.

Müslim, Ebu'l-Huseyin Müslim b. Haccac el-Kuşeyri. el-Câmi'u's-sahîh. İstanbul: Çağrı Yayınları, 1981.

Nisâbûri, Ebu Abdillah el-Hâkim. el-Müstedrak 'ala's-sâhîhayn. thk. Mustafa Abdu'l-Kadir Ata. 4 cilt. Beyrut: Dâru'l-kütübi'l-'ilmiyye, 1990.

Sancaklı, Saffet. “Hz. Peygamber'in Çocuklara Verdiği Değer Bağlamında Sokak Çocukları Sorununa Genel Bir Bakış". Selçuk Üniversitesi İlahiyat Fakültesi Dergisi. 21 (2016): 24.

Salim, Muammer. "Geçmişten Günümüze Türkiye'de Çocuk Koruma Politikaları ve Sosyal Hizmetler ve Çocuk Esirgeme Kurumu". Yüksek Lisans tezi, Süleyman Demirel Üniversitesi Sosyal Bilimler Enstitüsü, 2011.

Suyûti, Celaleddin b. Abdirrahman. ed-Dürrü'l-mensûr fi't-tefsîr bi'lme'sûr. 8 cilt. Beyrut: Dâru İhyâ, 1993.

Şahyar, Ayşe Esra. "Ümâme bint Hamza". Türkiye Diyanet Vakfı İslam Ansiklopedisi. Ankara: TDV Yayınları, 2012, 42: 301-302.

Taberânî, Süleyman b. Ahmed b. Eyyub ebu'l-Kasım. el-Mu'cemu'l-kebir. thk. Hamdi b. Abdu'l-Mecid es-Selefî. 20 cilt. Musul: Mektebetü'1Ulum ve'l-Hikme, 1983.

Tîbî, Şerafüddin Hüseyin b. Abdullah. el-Kâşif 'an hakâiki's-sünen (Şerhu'tTîbî alâ Mişkâti'l-Mesâbîh). thk. Abdülhamid Hindâvî. 13 cilt. Mekke: Mektebetü Mustafa el-Bâz, 1999.

Tuksal, Hidayet Şefkatli. Kadın Karşıtı Söylemin İslam Geleneğindeki İzdüşümleri. Ankara: Otto Yayınları, 2012.

Vâkidi, Muhammed b. Amr b. Vâkıd. Kitabu'l-meğâzi, thk. Marsden Jones. Beyrut: Alemu'l-Kütüb, 1966.

Yazır, Elmalılı M. Hamdi. Hak Dini Kur'ân Dili. 10 cilt. İstanbul: Azim Yayınları, 1992. 